\title{
The Effect of Input Quality, School Environment and Future orientation on Students' Accounting Competence
}

\author{
Dessy Ekaviana and Ahmad Nurkhin \\ Faculty of Economics, State University of Semarang
}

\begin{abstract}
The purpose of this study is aimed to determine the effect of the students' input quality for the accounting competence through the mediation of both school environment as well as the orientation of the future field of work. The study population is all twelve grade students of Accounting at SMK Negeri 2 Semarang who involve in Competency Test of Accounting Technician from Technician Professional Certification Institute in 2015. The technique of collecting data uses questionnaires and documentation. Data analysis technique used is descriptive statistical analysis and inferential statistical analysis.

The results showed that the quality of student input, the school environment, and the future-oriented field of work have significant positive effect on the accounting competence. Furthermore, the result is the school environment and future-oriented field of work proved as mediating variables influences the input quality on the students accounting competence.We conclude that the quality of student input affect the accounting competence both directly and indirectly through the school environment as well as the orientation of the future field of work. The recommendation given is schools can improve the completeness of school facilities for comfort and a more conducive learning environment. Next, enhance the future-oriented field of work of teachers and students through expanding partners connections business / industrial world for creating opportunities for students to work based on their field of expertise after the graduation.
\end{abstract}

Keywords: Quality of the Input, School Environment, Future Orientation, Student Competence, Accounting

\section{INTRODUCTION}

Vocational High School (SMK) is known as one of the educational institutions that is in charge in creating professional and productive generation who are ready to work and improve the quality of human resources through education and training. Industrial developments and competitive world which is increasingly demanding labor to have the adequate skills to perform a particular job. BPS statistics number from August 2015 showed the number of unemployed at vocational level reached $12.65 \%$ from the total number of unemployment in Indonesia. The figure has increased from 2014 in which the open unemployment rate at vocational level reached $11.24 \%$ of the total unemployed Indonesia. When compared with other levels of education, the unemployment rate in vocational education is the highest.

Sukardi (2013: 157) stated that the competency of vocational graduates consist of general competence and vocational competencies that each has to put a key competence. General competence refers to the national education goals and objectives of generic life, while vocational competence refers to the National Competence Indonesia (SKKNI). At the level of secondary vocational schools, the achievement of student competency at a certain level of expertise to be taken according to its competence in vocational measured through competency testing expertise.

National Professional Certification Board (BNSP) is an independent agency in charge of ensuring the quality of competence and recognition to the entire workforce across sectors of the profession in Indonesia through the certification process. In carrying out its duties and functions BNSP may grant a license to a Professional Certification Agency (LSP). LSP which has been licensed BNSP for the accounting profession that is the Professional Certification Institute of Accounting Technicians (LSP-TA). Meanwhile, one of the Accounting Competency Test (TUK) place has been accredited through the verification of the Accounting LSPTA in SMK Negeri 2 Semarang. SMK Negeri 2 Semarang is the only vocational school in Semarang that is certified as TUK Accounting since 2005.

Accounting technician competency test LSP TA for accounting students of SMK Negeri 2 Semarang is only followed by a minority of students. Based on interviews with accounting teacher, cost is quite high. Competency test LSP-TA followed by almost all new students conducted in 2015 due allowance for the competency test given to students and government policies on exemption miscellaneous school fees in any form so that students are not overburdened by the cost of the competency test LSP-TA. Based on the data obtained, it is found that the 96 students who take the competency test, only 45 students (46\%) of the total trial participants who declared competent on five areas of competence unit tested. 
The data that is interesting to be conducted as a research about the factors that affect student competencies of accounting. Syah (2008: 118) stated that the mastery of competencies is one manifestation of learned behavior. Suryosubroto (2010: 18) stated that in the learning process it involves their teachers, curriculum, environment, students, infrastructure, and organization. With so many factors that affect student competence, both from the students as well as students from the external environment.

This study is aimed to determine the effect of input quality, school environment, and the futureoriented field of work for the students' accounting competence. Purwanto (2007: 106) suggests the quality of student input is one of the important factors that affect learning outcomes. Several studies have shown a positive effect on the learning achievement of quality inputs (Fajariana 2011; Syamsurijal, 2012). Khafid (2008) found that environmental factors affect school learning completeness of accounting directly. Sudikno and Amina (2014) found that the school environment contributes greatly to the learning achievement.

In addition to the above two factors, the learning process that plays an important role in determining the outcome of learning is the students themselves. Anderman and Anderman (1998: 10) found a future-oriented educational effect on academic achievement. Lena (2007) found a significant difference between the future orientations of education on learning achievement. Leondari and Gonida (2008: 175) found that the orientation of the future effect on academic achievement. Seginer (2009: 172) argues that the orientation of the future of education and field work on effect on the academic achievement of high school students. Rohman (2013: 4) found that the orientation of the future affect student achievement high school in Jombang is $79.7 \%$.

\section{LITERATURE REVIEW}

\section{System Approach in Learning}

Purwanto (2007: 106) stated that learning is a process that can be seen through a systems approach. This statement is in line with the opinion of Suryosubroto (2010: 18) who stated that the educational process can be seen with the frame of the system. As a process, learning requires something to be processed (input or input) and the results of the processing (output or output). The concept of learning through a systems approach by Purwanto (2007: 106) can be described as follows:

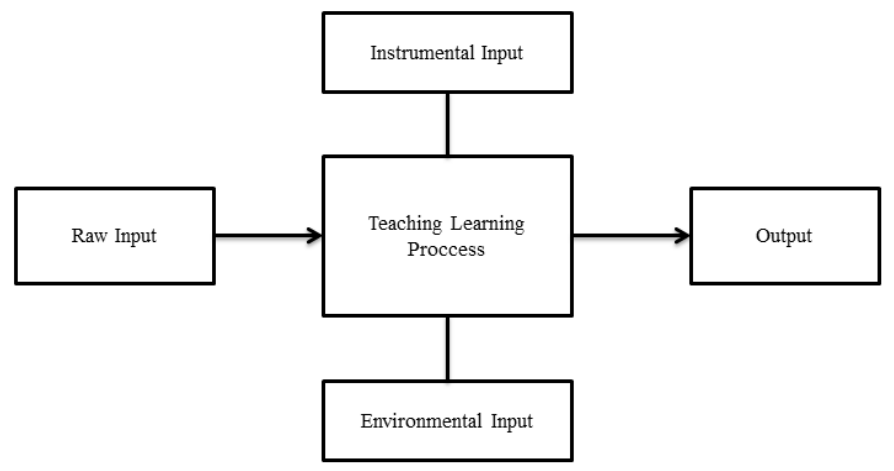

Figure 1 Mindset System in Learning Process

Figure 1 shows that the learning outcomes as the output of a system of learning is affected by the raw input and the learning process (teaching-learning process). The learning process itself is influenced by factors that are deliberately designed (instrumental input) such as curriculum and environmental factors such as school infrastructure. Furthermore, Suryosubroto (2010: 18) stated that the elements involved in the learning process are teachers, curriculum, environment, students, infrastructure, and organization of the school.

\section{ACCOUNTING COMPETENCE CONCEPT}

American Vocational Association (AVA) defines vocational education as "educational designed to develop skills, abilities, understanding, attitudes, working habits, and appreciations needed by workers to enter and the make progress in employment on useful and productive base" (Pitono, 2008: 29 ). Definition of secondary vocational schools according to Government Regulation No. 74 The 2008 chapter 1 verse 21 is one form of formal education unit which organizes vocational education at the level of secondary education as a continuation of the junior high school or other forms of equal or advanced learning outcomes recognized the same or equivalent junior high school or junior.

The competence of vocational high school graduates consisted of general competence and vocational competence, each of which already contained the key competencies. General competence refers to the national education goals and objectives of generic life, while vocational competence refers to the National Competence Indonesia (SKKNI). National Competence Indonesia (SKKNI) Accounting Technician 2013 stated that 
competence is defined as the ability required to perform or carry out work that is based on the knowledge, skills and work attitude. Thus, it can be formulated that competence is defined as the ability of a person who can be observed include the knowledge, skills, and work ethic in completing a job or task in accordance with the performance standards set.

The level of mastery of the knowledge, skills and abilities of individuals measured through a series of questions or exercises or another tool called the test (Suharsimi, 2013: 46). At the level of secondary vocational schools, the achievement of student competency at a certain level of expertise to be taken according to its competence in vocational measured through competency testing expertise. Competency test conducted by the Professional Certification Institute (LSP) which has been licensed by the National Professional Certification Board (BNSP). There are at least 30 LSP that have obtained a license from BNSP, including LSP Accounting Technicians (LSP-TA) which carry out certification of the accounting profession. LSP has licensed verifying the workplace or agencies that can provide test execution facilities competencies, hereinafter referred to Competency Test Sites (TUK).

Syah (2008: 132-139) suggests the factors that affect learning are as follows: (1) internal factors (factors of the students), covering aspects of the physiological and psychological aspects of students; (2) external factors (factors outside the student), environmental factors include social and environmental nonsocial; and (3) approach factors to learning, which is the type of student learning effort that includes strategies and methods that students use to conduct learning lesson materials.

\section{THE CONCEPT OF QUALITY OF STUDENT INPUT}

Purwanto (2007: 106-107) suggests that the raw input (raw input) is the raw material that needs to be processed. In the process of teaching and learning in schools, it is a raw input is a student. Suharsimi (2013: 4) argues that the input is the raw material that is incorporated into the transformation. In the world of schools, it is the raw material is prospective new students will enter the school. While Suryosubroto (2010: 18-19) states that the input is the raw material that comes from outside the system (environment) to be processed by the system. In the school system, the input here is the children who enter the school.

Before entering into a level (institutions), prospective students are assessed in advance capabilities. This assessment aims to determine whether the prospective future students will be able to follow the lessons and carry out the tasks that will be given to him (Suharsimi, 2013: 4). Furthermore, he argued that the prospective student as a whole person may be viewed from several aspects that generate various forms of tests used to measure. Aspect is the ability, personality, attitude, and intelligence. In addition to these aspects, other aspects into consideration recruitment of students as a raw input in the education process are a physical state, such as health, immunity, and susceptibility. Ongaki and Nyamiobo (2014: 186) stated that the quality of the product depends on the quality of the raw material input. In education, the quality of student input is very important to determine the quality of graduate students.

\section{CONCEPT OF SCHOOL ENVIRONMENT}

Syah (2008: 137) stated that the social environment of the school as teachers, administrative staff, and classmates can affect student learning. While Suryosubroto (2010: 19) stated that the environmental factors that affect the quality of graduate school including the quality of teachers, quality of infrastructure, quality and the climate of cooperation between teachers and learners, teachers with teachers, principals and teachers. All of these components determine the quality of teaching and learning process and determine the quality of graduates. Slameto (2013: 64-69) stated that environmental factors that affect learning in school are: teaching methods, curriculum, teacher and student relationships, student relationships with students, school discipline, teaching tools, school time, students above standard size, state building, methods of learning and homework

\section{THE CONCEPT OF FUTURE ORIENTATION}

The orientation of the future is one of the phenomena of cognitive development that occurs in adolescents (Desmita, 2009: 199). Nurmi (1989: 196) argues that the orientation of the future is a multidimensional process that includes motivation, planning, and evaluation. Beal (2011:4) argues that the orientation of the future can be explained by some theoretical concepts, such as the theory of the possibility of suicide, hope and fear, the future time perspective, as well as the aspirations and expectations. The possibility of self is positive and negative picture about the state of being in the future (Oyserman et al., 2006: 188). Aspiration is a set of goals / objectives to be achieved within a certain time. While expectations of a single target that was identified as the best alternative that can be achieved within a certain time. 


\section{FRAMEWORK FOR THINKING AND HYPOTHESES DEVELOPMENT}

Learning is a process that can be seen from the frame of the system. As a system, it is in education involves elements that interact with each other and work together as a unified whole in order to achieve certain goals. The elements in a functional system are comprised of the input, process and output. In terms of education, the input here is the prospective students who will enter the school, the process is defined as teaching and learning in schools that involve a variety of resources, while the output in this case is a graduate expected as a result of the input that has been processed through the provision of experience learn.

Secondary vocational schools is a formal education in secondary education that served mainly to develop the student's ability to perform certain types of work. The quality of vocational education applying double size, the quality according to school size and quality according to the size of the community. Quality according to school size covering the aspects of success in meeting the demands of learners who have been oriented towards curricular work demands. Vocational high school competence graduates consisted of general competence and vocational competence, each of which already contained the key competencies. General competence refers to the national education goals and objectives of generic life, while vocational competence refers to the National Competence Indonesia (SKKNI).

Competence is the ability required to perform or carry out work that is based on the knowledge, skills and work attitude. Thus, it can be formulated that competence is defined as the ability of a person who can be observed include the knowledge, skills, and work ethic in completing a job or task in accordance with the performance standards set. The level of mastery of the knowledge, skills and abilities of individuals measured through a series of questions or exercises or another tool called the test. At the level of secondary vocational schools, the achievement of student competency at a certain level of expertise to be taken according to its competence in vocational measured through competency testing expertise.

Selection of competency test LSP-TA accounting technician who has been licensed as an indicator of competence BNSP accounting students in this study include the entry into force of the Asean Economic Community (AEC) which requires certification of competence for labor. In addition, scoring systems on a competency test of LSP-TA. These include various types of tests both written in the form of theory and practice as well as the interview.

The output of the educational system is highly dependent on the quality of inputs (Suryosubroto, 2010: 19). Furthermore, it is stated that included in the components of the quality of student input include initial ability of students, students' backgrounds and circumstances parents. As mentioned by Bereday in Ongaki and Nyamiobo (2014: 186) that the quality of graduates of the previous educational levels directly affect the final result of the system of higher education. Results of research conducted by Fajariana (2011) showed that the quality of student input directly affect student learning outcomes.

There are factors that affect learning outcomes, both internal factors that are derived from the students as well as external factors that come from outside the student. One of the external factors that affect learning outcomes is the school environment. The school environment here is the curriculum, teaching methods are effective and fun, relationships of teachers with students who are close, relations between students who are near, facilities and adequate infrastructure, time and discipline of the school, and the school environment that is conducive to support teaching and learning activities, Results of research conducted by Sudikno and Amina (2014) found that neighborhood schools affects directly or indirectly on student achievement.

The orientation of the future is one of the internal factors that affect student learning outcomes. Field future orientation is often in the spotlight of research on adolescents, among others, future-oriented education, occupations, and areas of the wedding. Results of research conducted by Lena (2007) found that the orientation of the future of education directly affects learning achievement. It is further mentioned that the students who have clear future orientation have better academic achievement than students who do not have the clarity of future orientation.

The quality of student input also affects the future orientation of the field of the student's work. In harmony with the opinion of Erickson et al. in Holopainen and Sulinto (2005: 4) who argued that includes internal factors that affect the future orientation such as factors of personality, skills, and cognitive factors. While external factors that affect the future orientation among others is the time, historical, social, cultural, and physical factors of the individual. In this case the students' skills and cognitive factors can be seen through the initial ability of students. While external factors that affect the future orientation can be seen through the student's background and circumstances of parents. Sees education through the frame of the system, the input quality also affects the school environment. This is because the application of the admission at a particular school so that not all prospective students can be accepted at the school.

The school environment also affects the future orientation of students. This is in line with the results of research conducted by Oyserman et al. (2007: 479) which found that the role of the parent school influence on future orientation. Further stated that the orientation of the future act as a mediating influence of the role of the parent school learning outcomes of students.

Hypotheses 
H1: There is a positive and significant impact of the quality of student input competencyonAccounting for the welve grade of SMK Negeri 2 Semarang.

$\mathrm{H} 2$ : There is a positive and significant impact of student input quality of the schoolenvironment on Accounting for the twelve grades of SMK Negeri 2 Semarang

H3: There is a positive and significant impact of the school environment competence onaccounting for the twelve grade of SMK Negeri 2 Semarang

$\mathrm{H} 4$ : There is a positive and significant impact of the school environment future-oriented occupations on counting for the twelve grade student of SMK Negeri 2Semarang.

H5: There is a positive and significant impact of the quality of input on students' future-oriented field of ccounting work Accounting for the twelve grade of SMK Negeri2 Semarang.

H6: There is a positive and significant influence of future orientation on competenceoccupations accounting for the twelve grade of SMK Negeri 2 Semarang.

H7: There is a positive and significant impact of the quality of student input through theschool environment on the competence of accounting for the twelve grade of SMKNegeri 2 Semarang

H8: there is a positive and significant effect of the quality of student input through thefuture-oriented field of work on the competence of accounting for the twelve gradeof SMK Negeri 2 Semarang.H9: there is a positive and significant influence of the school environment throughfuture-oriented field of work on the competence of accounting for the twelve gradeof SMK Negeri 2 Semarang

\section{METHOD}

This research is a quantitative research, the method of research that is based on the philosophy of positivism. This study aimed to understand the influence of the quality of input on the competence of students through the school environment and future orientation as a mediating variable.

The population used in this study was all the twelve grade of Accounting at SMK Negeri 2 Semarang who joins Accounting Technician Competency Test organized by the Professional Certification Institute of Accounting Technicians (LSP-TA). The overall population of 96 students. The sampling technique used is the technique census or sample saturated. Thus, the sample used in this study is all members of the study population are 96 students.

The dependent variable in this research is the students' accounting competence. Indicators used to measure the competence of accounting are the result of Accounting Technicians Cluster Competence Test Preparing Financial Statements Based SAK ETAP organized by Professional Certification Institute of Accounting Technicians (LSP-TA).

The independent variables in this study are the quality of student input. The quality of student input is the initial ability of prospective students can be seen through the learning outcomes in the previous education level and assessment of candidate learners through a set of tests. Suryosubroto (2010: 19) stated that the quality of the components included in the student input as raw inputs include initial ability of students, students' backgrounds and circumstances parents. Indicators of the quality of student input in this study are: (1) Scores of the National Final Examination of junior high schools, (2) Special Test Score, (3) benefit Score, (4) Achievement Score, (5) Environmental Score. The use of indicator quality, based on the input of the student selection mechanisms admission of new students who applied in SMK Negeri 2 Semarang. This provision refers to Semarang Mayor Regulation No. 18 Year 2013 About the System and Procedure for Admission of Students in Semarang in 2013 and the Decree of the Head of Education Office of Semarang No. 420/2797.

Mediating variable in this study is the school environment and future-oriented field of work. The school environment is a student in the course of education to acquire knowledge, change attitudes, and life skills to follow and obey the rules in a systematic education that has been set. School environment indicators in this study refers to the opinion Slamet (2013: 64-69), which are (1) curriculum, (2) teaching methods, (3) the relationship of teachers and students, (4) the relationship of students with students, (5) discipline school, (6) school facilities, and (7) of school time. Future orientation field of student work is a description of student work in the future. Indicators of future orientation in this study is derived from the theory of a future orientation proposed by Nurmi (1989: 196-197), covering aspects (1) motivation, (2) planning, and (3) evaluation.

\section{DATA COLLECTION METHOD}

Data collection method used is the questionnaire and documentation. Questionnaire method is used to collect data on environmental school and future-oriented field variable of work. The type of questionnaire used in this study is a list of matches or checklist in which respondents are asked to sign $(\sqrt{ })$ to provide choice in the space provided. Measurements questionnaire using a five-point Likert scale so that on every statement in the instrument provided five possible answers. While the documentation method used to collect data on the quality of student input and accounting competencies for the twelve grade students of SMK Negeri 2 Semarang. 


\section{DATA ANALYSIS METHOD}

Methods of data analysis used in this research are the analysis of descriptive statistics and inferential statistical analysis. Descriptive statistical analysis is used to illustrate the Score of the maximum, minimum, sum, average, and standard deviation of each variable used in this study, namely accounting competence, quality of student input, the school environment, and future-oriented field of work. Meanwhile, inferential analysis method used is path analysis to examine the effect of mediating variables. Sobel test is also used to test the strength of the indirect effect of independent variables on the dependent variable in this study. IBM SPSS v2 1 software is used to analyze the data.

\section{RESULTS AND DISCUSSION}

Research Findings

The results of descriptive statistical analysis of research variables can be seen in Table 1 below.

Table 1 The Statistic Descriptive For Each Variable of the Study

\begin{tabular}{|l|l|l|l|l|l|}
\hline No. & Variable & Min & Max & Mean & $\begin{array}{l}\text { Std. } \\
\text { Deviation }\end{array}$ \\
\hline 1. & Input Quality & 72,14 & 89,10 & 78,33 & 4,06886 \\
\hline 2. & School Environment & 41,00 & 95,00 & 74,97 & 13,74769 \\
\hline 3. & Future Orientation & 48,00 & 119,00 & 93,00 & 14,73056 \\
\hline 4. & Accounting Competence & 71,02 & 94,35 & 83,89 & 4,78881 \\
\hline
\end{tabular}

Source: Research Data 2016

Table 2 The Summary of the Hypothesis Testing

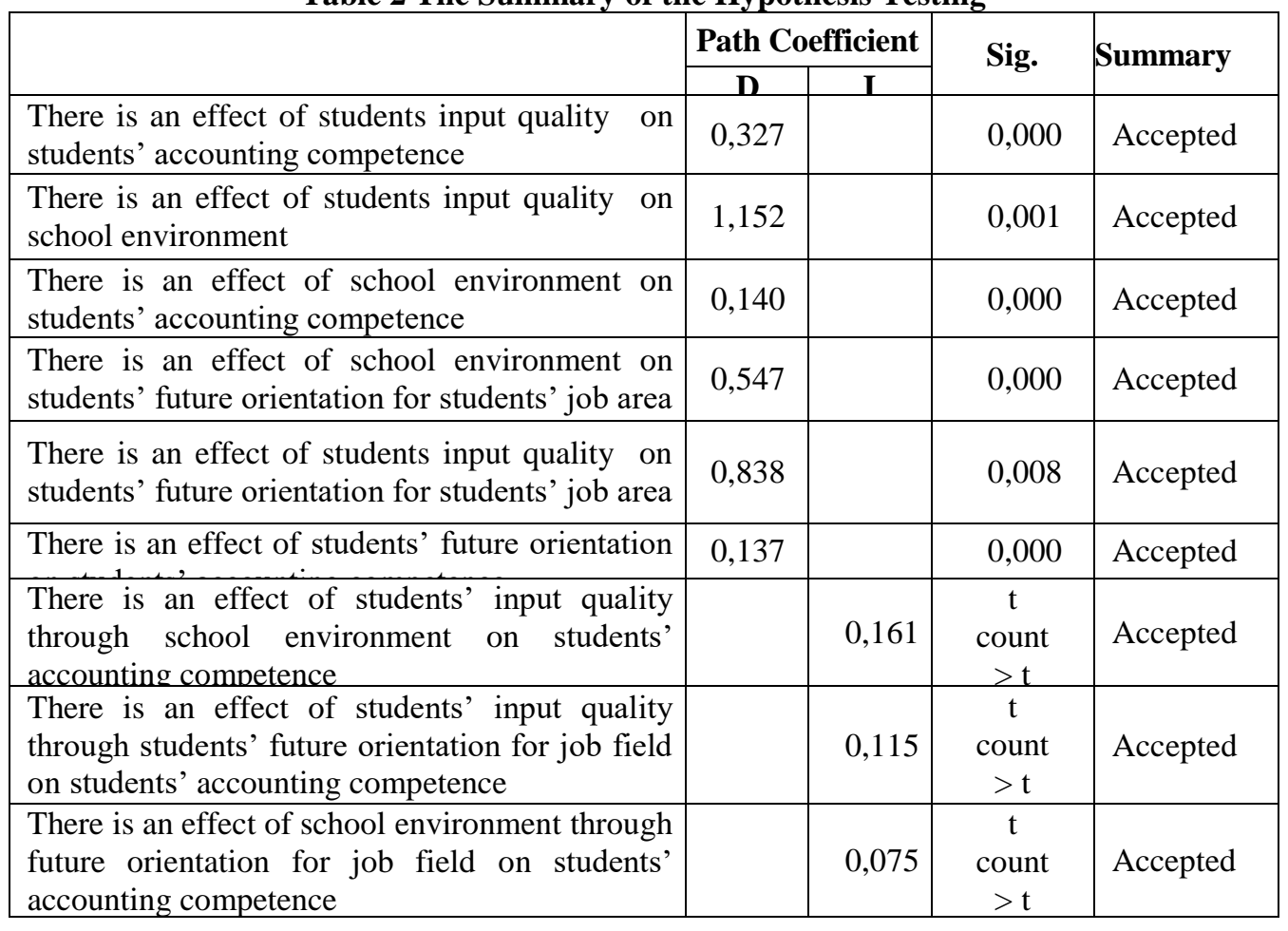

\section{DISCUSSION}

\section{The Effect of Student Input Quality on Accounting Competence}

The research finding showed that the quality of student input has positive and significant effect on the students' accounting competence. Major contribution of the quality of student input accounting competence is $34.20 \%$. Path coefficient score of student input quality of the accounting competence is 0.327 . The results are consistent with the theoretical approach of the education system in which the mastery of competencies at the outcome of an educational system of which is influenced by the raw input and the learning process that involves environmental input and input are intentionally designed and manipulated (instrumental input). What is meant by the raw input here is a new learner or student input (Puwanto, 2007: 106-107). 
The results also in line with the opinion of Suryosubroto (2010: 19) who stated that the learning outcome is determined by the quality of student input. Furthermore, it is stated that included in the components of the quality of student input include initial ability of students, students' backgrounds and circumstances parents. The results of the study support the research Fajariana (2011) which concluded that the quality of student input directly affect student learning outcomes.

\section{The Effect Of Input Quality On The Students' School Environment}

The results showed that the quality of student input has a positive and significant effect on the environment of the school. Great contribution to the quality of the school environment on student input is $11.63 \%$. Path coefficient Score input quality of students to the school environment is 1.152 . Students who have a national final exam scores good junior high school will likely choose to continue in secondary school are also good. This statement is in line with the results of research by Kurniyati (2014) who found that the socioeconomic status of parents affects the school environment.

\section{The Effect Of School Environment Onaccounting Competence}

The results showed that the school environment has a positive and significant effect on the students, accounting competence. Great contribution to the school environment accounting competence is 55.35\%. Path coefficient Score of student input quality of the accounting competence is 0.140 . The results of this study are consistent with the approach of systems theory in education mastery of competencies as part of the learning outcomes which is the output of an education system is influenced by the quality of student input and the learning process that involves environmental input and feedback instrumental (Purwanto, 2007: 106 and Suryosubroto, 2010: 19). The results also support findings Sudikno and Amina (2014) concluded that there is an influence of the school environment on students' achievement.

\section{The Effect Of School Environment On Future Orientation}

The results showed that the school environment influence the orientation of the future field of work. Great contribution to the school environment future-oriented field of work is $34.69 \%$. Path coefficient Score of the school environment to the orientation of the future field of work was 0.547 . The results are consistent with the opinion of Nurmi, Poole, and Kalakoski in Holopainen and Sulinto (2005: 4) which states that the external factors affecting the future orientation of which is time, historical, social, cultural, and physical factors of the individual. Included in the socio-cultural factors that influence future orientation is the school environment.

\section{The Effect Of Quality Student Input On Future Orientation}

The research finding showed that the quality of student input has a positive and significant impact on the future-oriented field of work. Major contribution to the quality of input students' future-oriented field of work is $16.40 \%$. Path coefficient Score of quality of student input to the orientation of the future field of work was 0.838 . The results are consistent with the opinion of Erickson, Havighurst, and Nurmi in Holopainen and Sulinto (2005: 4) who stated that the future orientation of individuals affected by internal factors such as: personality, skills, and cognitive factors. The results also consistent with research done by Iovu (2014) who found that parental influence on the future orientation of high school students.

\section{The Effect Of Future Orientation On The Accounting Competence Students}

The results showed that the future-oriented field of work occupations has a positive and significant effect on the students' accounting competence. Large contributions orientation of the future areas of work for the competence of accounting is 59.14\%. Path coefficient score orientation of the future areas of work for the competence of accounting is 0.137. The results are consistent with the opinion of Seginer (2009: 172) states that the orientation of the future education and employment affect the academic achievement of high school students. He concluded that the orientation of the future has a strong and stable relationship with learning outcomes.

The results are consistent with research done by Oyserman, Bybee, and Terry (2006) found that the orientation of the future effect on learning outcomes. Lena (2007) found that the orientation of the future of education has exhibited significantly influence on learning achievement. Rohman (2013) found that the orientation of the future effect on student achievement high school in Jombang amounting to $79.70 \%$.

\section{The Effect Of Environmental Quality Input Students Through The School Of Accounting Competence}

The results showed that there are significant qualities of student input through the school environment for the competence of accounting positively and significantly. Sobel test is performed to produce 3,080 $t$ of significance mediation. T count> $\mathrm{t}$ table 1.985 at the 0.05 level so it can be concluded that the influence of the quality of student input through the school environment is a significant accounting competence. The research 
result is in line with systems theory approaches in education. Mastery of competencies as one form of learning outcomes is the output of the system is affected by the input of raw or quality of student input and the transformation or the process of teaching and learning activities that are subject to these inputs. The learning activities are influenced by environmental input and feedback instrumental. This is in line with the opinion of Purwanto (2007) and Suryusubroto (2010: 19).

\section{The Effect Of Input Quality On The Future Students'Orientation With Field Work On Accounting Competence}

The research finding showed that the quality of student input through the future-oriented field of work for the competence of accounting has a significant positive effect. Sobel test conducted gained t Score 2.485. T count> t table 1.985 at the 0.05 level so it can be concluded that the influence of the quality of student input through the future-oriented field of work against the accounting competence is significant.

The results of the study in accordance with the approach of systems theory in education mastery of competencies as output system is affected by the quality of student input and the learning process or transformation. The learning process or the transformation involves various elements including teachers, curriculum, environment, infrastructure, organization of the school, and the students themselves (Suryosubroto, 2010: 18). The results of study a student is influenced by internal and external factors. One of the internal factors that affect learning outcomes is the psychological factors of students. The orientation of the future is one of the psychological factors that influence student learning outcomes. Students who have a future-oriented field of high job will always try to realize the self-image that will be achieved in the future so that he will always strive to improve the quality of its self.

The Effect Of School Environment Through FutureOrientation Field Work On Accounting Competence The research finding showed that the school environment through future-oriented field of work for the competence of accounting has a significant positive effect. Sobel test performed has gained t Score 4.463. T count $>\mathrm{t}$ table 1.985 at the 0.05 level. It can be concluded that the influence of the school environment through future-oriented field of work on the accounting competence is significant. The results of this study are relevant to the research Oyserman, Brickman, and Rhodes (2007) who found that the orientation of the future mediating role of the school environment on learning achievement. Future orientation is a picture of you in the future that can help individuals to drive her to achieve the desired goals in the future. Learners who have high future orientation to work in the accounting field will constantly improve themselves possessed to achieve the desired self-image in the future. The orientation of the future includes the dimensions of motivation, planning, and evaluation. In the dimensions of motivation there is a commitment to realize self-image in the future in accordance wanted. This commitment will bring the impact that someone who has a future orientation field of high employment is not easily affected by the environment that does not support the interest in self-image in the future it has.

\section{CONCLUSION}

The conclusions of this research are that the input quality, the school environment, and future orientation have been proved to have a positive and significant impact on students' competency. Variable of quality of inputs and the school environment also proved to have a positive and significant impact on the future orientation. Another result is that the school environment variables and future orientation proved as mediating variables influence the quality of the input to the competence of students. Lastly, future orientation proved to be a mediating variable environmental influences school on student competency. The advice given is schools can improve the completeness of school facilities for comfort and a more conducive learning environment and enhance the future-oriented field of work of teachers and students through expanding partners connections for business / industrial world for creating opportunities for students to work in their expertise after graduation later.

\section{REFERENCE}

[1] Anderman, Eric M. and Lynley Hicks Anderman. 1998. Present and Possible Selves During Early Adolescence. Paper presented at the bi-annual meetingof the Society for Research on Adolescence, March 1998.

[2] Suharsimi. 2013. Dasar-dasar Evaluasi Pendidikan (Edisi 2). Jakarta: Bumi Aksara.

[3] Beal, Sarah J. 2011. The Development of Future Orientation: Underpinnings and Related Constructs. Disertasi. Lincoln: University of Nebraska.

[4] BPS. 2015. Agustus 2015: Tingkat Pengangguran Terbuka (TPT) Sebesar 6,18 Persen. http://bps.go.id/brs/view/1196. (diakses pada 4 Februari 2016).

[5] Desmita. 2009. Psikologi Perkembangan. Bandung: Remaja Rosdakarya.

[6] Fajariana, Dewi Endah. 2011. Pengaruh Kualitas Input, Kompetendi Guru, dan Sarana Prasarana Sekolah Terhadap Prestasi Belajar Siswa. Tesis. Malang: Universitas Negeri Malang. 
[7] Holopainen, Laura and Sonja Sulinto. 2005. Adolescents Health Behaviour and Future Orientation. Thesis. Spring: Department of Psychology University of Jyvaskyld.

[8] Iovu, Mihai Bognan. 2014. How Do High School Seniors See Their Future?. Social Change Review. Summer 2014. Vol. 12 (1): 25-42.

[9] Kurniyati, Eni. 2015. Determinan Minat Melanjutkan ke Perguruan Tinggi Siswa Kelas XII IPS SMA Negeri di Banjarnegara. Skripsi. Semarang: Universitas Negeri Semarang.

[10] Khafid, Muhammad. 2008. Faktor-faktor yang Mempengaruhi Ketuntasan Belajar Akuntansi: Motivasi Belajar Sebagai Variabel Intervening. Lembaran Ilmu Kependidikan Vol. 37, No. 1. Hal 46-54. Juni 2008.

[11] Lena. 2007. Hubungan antara Orientasi Masa Depan dalam Bidang Pendidikan dengan Prestasi Belajar Mahasiswa/i Tahun Pertama (Penelitian pada Mahasiswa/i Fakultas Psikologi Unika Atma Jaya Angkatan 2006). Tesis. Jakarta: Unika Atmajaya.

[12] Leondari, Angeliki dan Eleftheria N. Gonida. 2008.Adolescent's Possible Selves, Achievement Goal Orientations, and Academic Achievement. Hellenic Journal of Psychology Vol. 5, Hal 179-198.

[13] Nurmi, Jari Erik. 1989. Development of Orientation to the Future During Early Adolescence: A four year Longitudinal Studi and Two Cross Sectional Comparisons. International Journal of Psychology 24. Hal 195-214.

[14] Ongaki, Nickson Moseti and John Karori Nyamiobo. 2014. The Challenges of Infusing Total Quality Management in Kenyan Public University System. The International Journal of Business \& Management, Volume 2 Issue 7. Hal 184-190. Juli 2014.

[15] Oyserman, Daphna, Deborah Bybee and Kathy Terry. 2006. Possible Selves and Academic Outcomes: How and When Possible Selves Impel Action. Journal of Personality and Social Psychology, Vol. 9, No.1, Page 188-204.

[16] Oyserman, Daphna, Daniel Brickman and Marjori Rhodes. 2007. School Success, Possible Selves, and Parent School Involvement. Family Relations Vol. 56, No.5. December 2007.

[17] Peraturan Pemerintah Republik Indonesia Nomor 74 Tahun 2008 tentang Guru.

[18] Peraturan BNSP Nomor 305 Tahun 2013 Tentang Pedoman Pelaksanaan Uji Kompetensi Oleh Panitia Teknis BNSP. Jakarta: BNSP.

[19] Pitono, Joko. 2008. Pengaruh Pelaksanaan Praktik Kerja Industri/Instansi dan Kemandirian BelajarTerhadap Mutu Lulusan Program Keahlian Akuntansi. Tesis. Surakarta: Program Pasca Sarjana Universitas Sebelas Maret.

[20] Purwanto, Ngalim. 2007. Psikologi Pendidikan. Bandung: Remaja Rosdakarya.

[21] Rohman, Muhammad Minan Nurir. 2013. Pengaruh Kejelasan Orientasi Masa Depan dan Motivasi Belajar Terhadap Prestasi Belajar Siswa Sekolah Menengah Atas. Jurnal Economica Sekolah Tinggi Keguruan dan Ilmu Pendidikan Persatuan Guru Republik Indonesia.

[22] Seginer, Rachel. 2009. Future Orientation: Developmental and Ecological Prespectives. Haifa: University of Haifa.

[23] Slameto. 2013. Belajar dan Faktor-Faktor yang Mempengaruhinya. Jakarta: Rineka Cipta.

[24] Sudikno, Iyut Sustiasih dan Yustina Sri Aminah. 2014. Pengaruh Lingkungan Keluarga, Lingkungan Sekolah, Disiplin Belajar, dan Motivasi Belajar Terhadap Prestasi Belajar Ekonomi Siswa SMA Kelas XI IPS SMA PGRI 1 Taman Pemalang. Economic Education Analysis Journal (3) (1) 2014. Hal 4651.

[25] Sukardi. 2013. Profil Kompetensi Siswa SMK Kompetensi Keahlian Teknik Kendaraan Ringan di Kota Pekalongan. Jurnal Pendidikan Vokasi. Hal 153-162.

[26] Suryosubroto. 2010. Manajemen Pendidikan di Sekolah. Jakarta: Rineka Cipta.

[27] Syamsurijal, Jarot. 2012. Analisis Daya Prediksi Beberapa Aspek yang Dipertimbangkan Dalam Penerimaan Peserta Didik Baru (PPDB) SMK Negeri Terhadap Prestasi Peserta Didik. Tesis. Denpasar: Universitas Pendidikan Ganesha.

[28] Syah, Muhibin. 2008. Psikologi Belajar. Jakarta: PT Raja Grafindo Persada.

[29] Undang-Undang Republik Indonesia Nomor 13 Tahun 2003 tentang Ketenagakerjaan. 